\title{
In vitro expansion of human glioblastoma cells at non- physiological oxygen tension irreversibly alters subsequent in vivo aggressiveness and $\mathrm{AC} 133$ expression
}

\author{
ERIKA BOURSEAU-GUILMAIN ${ }^{1}$, LAURENT LEMAIRE ${ }^{1}$, AUDREY GRIVEAU $^{1}$, \\ ERIC HERVOUET ${ }^{4}$, FRANÇOIS VALLETTE $^{4}$, FRANÇOIS BERGER ${ }^{2}$, PHILIPPE MENEI $^{1,3}$, \\ JEAN-PIERRE BENOIT $^{1}$, DIDIER WION ${ }^{2}$ and EMMANUEL GARCION ${ }^{1}$
}

\begin{abstract}
${ }^{1}$ Laboratoire d'Ingénierie de la Vectorisation Particulaire, Inserm, UMR_S 646, Université d'Angers, Angers;
${ }^{2}$ Institut des Neurosciences, Inserm, UMR_S 836, Université Joseph Fourier, Grenoble; ${ }^{3}$ Département de Neurochirurgie, CHU, Angers; ${ }^{4}$ Centre de Recherche en Cancérologie (CRCNA), Inserm, UMR_S 892, Université de Nantes, Nantes, France
\end{abstract}

Received September 7, 2011; Accepted October 19, 2011

DOI: 10.3892/ijo.2011.1271

\begin{abstract}
Among markers of glioblastoma initiating cells, AC133 has been shown to be associated with glioblastoma resistance and malignancy. Recently, it was demonstrated that increasing oxygen tension $\left(\mathrm{pO}_{2}\right)$ down-regulated $\mathrm{AC} 133$ expression in glioblastoma cells in vitro. In order to better understand extrinsic factor regulation of $\mathrm{AC} 133$, this work aimed to investigate the relationship between cell culture $\mathrm{pO}_{2}, \mathrm{AC} 133$ expression, and tumor development and phenotype. Using treatments with $\mathrm{CoCl}_{2}$ and $\mathrm{HIF}-1 \alpha$ shRNA knockdowns on nonsorted human primary glioblastoma cells cultured at low (3\%) versus high (21\%) oxygen tension, we established a responsibility for low $\mathrm{pO}_{2}$ in the maintenance of high levels of $\mathrm{AC} 133$ expression, with a major but non-exclusive role for HIF-1 $\alpha$. We also demonstrated that human glioblastoma cells previously cultured under high oxygen tension can lose part of their aggressiveness when orthotopically engrafted in SCID mice or lead to tumors with distinct phenotypes and no re-expression of AC133. These observations showed that the specific $\mathrm{pO}_{2}$ microenvironment irreversibly impacts glioblastoma cell phenotypes, highlighting the pertinence of culture conditions when extrapolating data from xenogenic models to human cells in their source environment. They also raised AC133 as a marker of non-exposure to oxygenated areas rather than a marker of aggressiveness or low $\mathrm{pO}_{2}$ niches.
\end{abstract}

\section{Introduction}

Central nervous system glioblastomas are among the most aggressive and treatment-resistant cancers. The recent discovery

Correspondence to: Dr Emmanuel Garcion, Institut National de la Santé et de la Recherche Médicale, Inserm U646, IBS - CHU Angers, 4 rue Larrey, 49933 Angers cedex 9, France

E-mail: emmanuel.garcion@univ-angers.fr

Key words: glioblastoma, CD133, tumor niche, cancer stem cell culture, HIF-1 $\alpha$ of self-renewing and uniquely tumorigenic brain tumor stem cells (BTSCs) (1-4), also referred to as brain cancer initiating cells, points to the presumption that this cancer stem cell subpopulation intrinsically resistant to radio and chemotherapeutic treatments might be responsible for the phenotypical derivation of tumors and their recurrence.

Instead of specific markers, makers shared with cancer stem cells $(5,6)$ and BTSCs, such as AC133 (2), CD15 (7), and CD171 (8), have been documented. Among these, AC133, an epitope of the CD133 protein, which is itself a pentaspan glycoprotein identified firstly on hematopoietic stem cells, is the best known (9-12). In vitro, in the presence of EGF, FGF-2, and heparin, AC133 expressing cells isolated from human glioblastoma regenerate, form neurosphere-like colonies and are capable of generating cells that express markers of differentiated neural cells (2). In xenograft models using immunodeficient mice, they lead to cancers that are phenotypically similar to the original tumors (2). AC133-positive cancer cells are also particularly resistant to radiotherapy (13) and TRAIL-mediated apoptosis (14). In addition, these cells are capable of promoting tumor neovascularization by producing VEGF (15). Finally, AC133 overexpression in human gliomas is associated with poor clinical outcome (16).

Although these findings are in line with the relevance of developing targeted strategies against BTSCs in glioblastomas through AC133 recognition, other observations argue for a more complex reality. Indeed, while less tumorigenic than their AC133-positive counterparts (3), AC133-negative cells can lead to tumors with a distinct phenotype (17). Moreover, the occurrence of BTSCs does not exclude the existence of cellular networks in which individually non-tumorigenic cell populations might cooperate to produce tumors (18). In addition, the tissue microenvironment might exert pivotal effects for tumor development $(18,19)$, and extrinsic cell modulators may drive the expression of intrinsic markers.

In line with this, AC133 expression in glioblastoma has been associated either with anatomical while not necessarily functional perivascular niches (20) or hypoxic pseudopalissading necrotic regions $(21,22)$. Thus, it is not yet understood whether 
AC133 incidence in those areas is due to improved survival of AC133-positive cells or positive regulation of $\mathrm{AC} 133$ expression. As oxygen is involved in the stem cell behavior (23) and tumor aggressiveness of human glioblastoma (24), it is important to consider its role on AC133 expression and AC133-positive BTSC performance. As such, it has recently been demonstrated that exposure to low oxygen tension $\left(\mathrm{pO}_{2}\right)$ allows for maintenance of the AC133 phenotype of non-sorted human glioblastoma cells in vitro (25). In addition, sorted AC133-positive human glioblastoma cells preserve their stem cell phenotype under low oxygen tension in vitro (26).

Nonetheless, these studies did not address how cell culture $\mathrm{pO}_{2}$ might affect the AC133 phenotype and the behavior of cancer cells following implantation in animals. In our study, we demonstrate that xenogenic experimental tumors, obtained from non-sorted human glioblastoma cells cultured either at 3 or $21 \% \mathrm{O}_{2}$, can significantly differ. In this context, we investigate whether $\mathrm{AC} 133$ is an indicator of low oxygen tension or of tumor aggressiveness. Finally, we discuss our data regarding the relevance of biopsy-derived models for functional investigations or for therapeutic targeting purposes.

\section{Materials and methods}

Patient tissue samples and human glioma cell cultures. Specimens from patients undergoing biopsy for de novo glioma were obtained from the Department of Neurosurgery of the Angers CHU (France), and from the Department of Neurosurgery of the Grenoble CHU (France), with institutional review board approvals. Pathologic diagnosis established that GlioA, GlioB, and GlioC tumor samples were grade IV WHO glioblastomas. Straight after tissue dissociation as previously described (25), cells were plated on uncoated plastic flasks at $2 \times 10^{4} / \mathrm{ml}$ of defined medium and cultured at $37^{\circ} \mathrm{C}$ under an atmosphere containing $5 \% \mathrm{CO}_{2}$ and either 3 or $21 \% \mathrm{O}_{2}$. GlioA, GlioB and GlioC were cultured in Dulbecco's modified Eagle's medium: Nutrient Mixture F-12 (DMEM/F12, Biowhittaker, Verviers, Belgium) added with Glutamax, B27 and N2 supplements (Invitrogen, Cergy Pontoise, France), recombinant human EGF and FGF-2 (20 ng/ml each, R\&D Systems Europe, Lille, France), and heparin ( $5 \mu \mathrm{g} / \mathrm{ml}$, Sigma-Aldrich, Lyon, France). Growth factors and supplements were added every 3 days for a period of 10-15 days, until new dissociations with Versene (Lonza, Levallois-Perret, France) and re-plating following initial culture setting. Under these permanent conditions, cells grew and were maintained as floating neurosphere-like colonies.

AC133 labeling and flow cytometry. Glioma cells exposed to different oxygen tensions were collected and dissociated using Versene (Lonza). A total of $1.5 \times 10^{5}$ cells were incubated with $5 \mu \mathrm{g} / \mathrm{ml}$ AC133 antibody (Miltenyi Biotech, Paris, France) or IgG1 isotype control (BD-Biosciences, Le Pont-de-Claix, France) for $1 \mathrm{~h}$ at $4^{\circ} \mathrm{C}$ in PBS containing 5\% FBS and $0.02 \%$ sodium azide. Cells were then washed three times in PBS containing 5\% FBS and $0.02 \%$ sodium azide, and incubated for $30 \mathrm{~min}$ at $4{ }^{\circ} \mathrm{C}$ with FITC-conjugated goat anti-mouse IgG F(ab') $)_{2}$ fragment polyclonal antibody (Dakocytomation, Trappes, France) at $20 \mu \mathrm{g} / \mathrm{ml}$ in PBS containing 5\% FBS and $0.02 \%$ sodium azide. Following three more washes in PBS containing 5\% FBS and $0.02 \%$ sodium azide, cells were re-suspended in PBS containing $2 \%$ formaldehyde and $0.02 \%$ sodium azide. A BD FACSCalibur ${ }^{\mathrm{TM}}$ fluorescent-activated flow cytometer and the BD CellQuest ${ }^{\mathrm{TM}}$ software (BD-Biosciences) were used in order to proceed to flow cytometry acquisition. Analysis was carried out using WinMDI 2.9 software (Scripps Institute, La Jolla, CA, USA).

Treatment of human glioma cells with cobalt dichloride $\left(\mathrm{CoCl}_{2}\right)$. GlioA, GlioB, and GlioC human glioblastoma cells were dissociated in Versene (Lonza). They were then plated at $37.5 \times 10^{5}$ cells per $\mathrm{ml}$ in the aforementioned media and incubated in the presence of vehicle alone (PBS) or $100-150 \mu \mathrm{M} \mathrm{CoCl}_{2}$ for $24 \mathrm{~h}$ at $37^{\circ} \mathrm{C}, 5 \% \mathrm{CO}_{2}$ and $3 \% \mathrm{O}_{2}$.

shRNA knockdown. Glioblastoma cells were stably transfected using control transduction particles (SHC001V) or shRNA transduction particles expressing siRNA against HIF-1 $\alpha$ (IDs: TRCN0000003810, TRCN0000003811 and TRCN0000010819), according to the manufacturer's instructions (Mission ${ }^{\circledR}$ pLKO.1puro lentiviral particles, Sigma-Aldrich). Cells were seeded at $5 \times 10^{3}$ in 96-well plates in supplemented neurobasal medium, and infected with a multiplicity of infection of 2 . Puromycine $(1 \mu \mathrm{g} /$ ml, Sigma-Aldrich) selected infected cells.

Q-PCR. Q-PCR analyses were carried out using a Chromo $4^{\mathrm{TM}}$ (Bio-Rad, Marnes-la-Coquette, France) and SYBR Green detection (iQ-SYBR Supermix, Bio-Rad). Primers were designed using Primer3 software (http://frodo.wi.mit.edu/primer3/). The $\Delta \mathrm{Ct}$ method was retained for quantification, and multiple genes were used for normalization, as previously described (27).

Orthotopic xenograft assays. GlioA and GlioB human glioblastoma cells, grown at 3 or $21 \% \mathrm{O}_{2}$, were dissociated in Versene, washed, and resuspended at 50,000 cells in $5 \mu \mathrm{l}$ Eagle's minimum essential medium (EMEM, Biowhittaker). SCID female mice (Charles River) were anesthetized using xylazine $(50 \mu \mathrm{g} / \mathrm{g})\left(\right.$ Rompun $^{\circledR}$, Bayer, Puteaux, France) and Ketamine $(10 \mu \mathrm{g} / \mathrm{g})\left(\right.$ Clorketam $^{\circledR}$, Vétoquinol, Lure, France). Stereotactic implantation of the $5 \mu \mathrm{l}$ cell suspension was carried out into the right striatum using a Hamilton syringe and a 32-gauge needle at the following coordinates: $0.5 \mathrm{~mm}$ anterior from Bregma, $2 \mathrm{~mm}$ lateral from the saggital suture, and $3 \mathrm{~mm}$ below dura. Cells were injected progressively over $2.5 \mathrm{~min}$, followed by $5 \mathrm{~min}$ of waiting, and progressive needle removal from brain over $6 \mathrm{~min}$. MRI was used to monitor tumor growth. The Kaplan-Meier method was used to plot animal survival. Animal care was carried out in line with relevant European Community regulations (Official Journal of European Community L358 12/18/1986).

Magnetic resonance imaging. Experiments were performed with a Bruker Avance DRX 300 (Bruker, Wiessembourg, France), equipped with a vertical super wide bore magnet and shielded gradient insert. The resonant circuit of the nuclear magnetic resonance (NMR) probe was a $38-\mathrm{mm}$ diameter birdcage. Rectal temperature was maintained at $37^{\circ} \mathrm{C}$ by using a feedbackregulated heating pad. Brain lesion evolution was assessed using T2-weighted images obtained using a rapid acquisition with relaxation enhancement (RARE) $(\mathrm{TR}=2000 \mathrm{~ms}$; effective echo time $=31.7 \mathrm{~ms} ;$ RARE factor $=8 ; \mathrm{FOV}=2.5 \times 2.5 \mathrm{~cm}$; matrix 128x128; nine contiguous slices of $1.2 \mathrm{~mm}$, four averages). In order to improve tumor detection, FLAIR imaging was 
Table I. Glioblastoma cells cultured at low $\mathrm{pO}_{2}$ expressed improve levels of $\mathrm{AC} 133$ than those cultured at high $\mathrm{pO}_{2}{ }^{a}$.

\begin{tabular}{lccc}
\hline & $\begin{array}{c}\text { GMFI at } \\
3 \% \mathrm{O}_{2} \\
\text { (arbitrary } \\
\text { units) }\end{array}$ & $\begin{array}{c}\text { GMFI at } \\
21 \% \mathrm{O}_{2} \\
\text { (arbitrary } \\
\text { units) }\end{array}$ & $\begin{array}{c}\text { Mean variation } \\
\text { of AC133 } \\
\text { expression } \\
\text { per cell }\end{array}$ \\
\hline $\begin{array}{l}\text { GlioA } \\
\text { (passage 21) }\end{array}$ & $77.42 \pm 0.15$ & $1.03 \pm 0.25$ & $-98.7 \%$ \\
$\begin{array}{l}\text { GlioB } \\
\text { (passage 14) }\end{array}$ & $16.70 \pm 0.56$ & $2.08 \pm 0.15$ & $-87.6 \%$ \\
$\begin{array}{l}\text { GlioC } \\
\text { (passage 11) }\end{array}$ & $52.07 \pm 1.59$ & $0.65 \pm 0.17$ & $-98.7 \%$ \\
\hline
\end{tabular}

aGlioA, GlioB, and GlioC glioblastoma primary cells were cultured at 3 or $21 \% \mathrm{O}_{2}$ and analyzed for $\mathrm{AC} 133$ expression using the anti-AC133 monoclonal antibody (AC133) or an $\mathrm{IgG} 1 \kappa$ isotype control $(\mathrm{IgG} 1 \kappa)$. FITC fluorescence revealed after application of the corresponding secondary antibody was expressed in geometric mean fluorescence intensity (GMFI) arbitrary units. Mean variation of AC133 expression per cell was calculated according to GMFI obtained at 3 versus $21 \%$ $\mathrm{O}_{2}$.

performed using a $600 \mathrm{~ms}$ inversion pulse prior to the RARE pattern, providing enough time to allow for the annulling of the normal parenchyma and therefore tumor detection.

Immunohistochemistry. Brains from xenotransplanted mice were surgically removed, snap-frozen in isopentane cooled at $-35^{\circ} \mathrm{C}$ with liquid nitrogen, and stored at $-80^{\circ} \mathrm{C}$ before $10 \mu \mathrm{m}$ transverse sections of anterior brain were made using a Cryocut 3000 (Leica, Rueil-Malmaison, France). After at least $24 \mathrm{~h}$ storage at $-20^{\circ} \mathrm{C}$ and 30 min drying at room temperature, slides were fixed in $-20^{\circ} \mathrm{C}$ cold methanol for $10 \mathrm{~min}$. Sections were then blocked with $10 \%$ normal goat serum in PBS added with $4 \%$ bovine serum albumine for $30 \mathrm{~min}$ at room temperature. Primary antibodies against CD133 (clone AC133 and clone 293C3 both from Miltenyi Biotech) and the corresponding negative isotype controls (mouse IgG1 $\kappa$ and mouse IgG2b, both from BD Biosciences) were diluted in PBS containing 4\% BSA and used at $5 \mu \mathrm{g} / \mathrm{ml}$. They were applied overnight at $4^{\circ} \mathrm{C}$. After washes in PBS, a secondary biotinylated goat anti-mouse IgG antibody (Vector Laboratories, Burlingame, USA) diluted in PBS containing $4 \%$ BSA was applied at $15 \mu \mathrm{g} / \mathrm{ml}$ for $45 \mathrm{~min}$ at room temperature. After additional washes in PBS, Alexa Fluor ${ }^{\circledR} 488$ streptavidine conjugates (Invitrogen, Cergy Pontoise, France) were applied in the dark at $4 \mu \mathrm{g} / \mathrm{ml}$ for $45 \mathrm{~min}$. Finally, labeled sections were washed three times with PBS before mounting in fluorescent mounting medium from Dakocytomation. All slides were examined under an Axioskop-2 Zeiss fluorescence microscope (Le Pecq, France). Images were acquired through a Photometrics CoolSNAP ES camera equipped with a QImaging CRI Micro Color 2 RGB Liquid Crystal filter and by using the MetaVue $^{\mathrm{TM}}$ imaging system (all from Roper Scientific, Evry, France).
Statistical analysis. XLSTAT 2006 Version 2006.3 (Addinsoft Paris, France) was used for data analysis. Statistical significance for each experiment was determined by a Dunnett's test. Alternatively, the Gehan-Wilcoxon and the Mann and Whitney non-parametric tests were used. The tests were considered as significant with $\mathrm{p}<0.05$.

\section{Results}

Oxygen tension impacts the AC133 phenotype of human glioma cells in vitro. To determine the effect of oxygen pressure on AC133 expression in non-sorted primary human glioblastoma cells, GlioA, GlioB, and GlioC were cultured either at $3 \% \mathrm{O}_{2}$ or $21 \% \mathrm{O}_{2}$. High expression of $\mathrm{AC} 133$ was found in all cell lines when maintained at low oxygen tension (from initial suspensions to at least passage 30). As such, at matching cell passages flow cytometry analysis revealed that the percentage of AC133positive cells was improved from 3 to $21 \% \mathrm{O}_{2}$ condition (Fig. 1). Quantification of geomean fluorescence intensity further indicated a mean reduction of $\mathrm{AC} 133$ expression per cell up to $99 \%$ between 21 and $3 \% \mathrm{O}_{2}$ (Table I).

A role for HIF-1 $\alpha$ in the regulation of AC133 expression. Having established a role for oxygen tension in the regulation of AC133, we next investigated whether HIF-1 $\alpha$ a major transcription factor regulated by oxygen tension, was involved in this effect. HIF-1 $\alpha$ has been described to be over-expressed in various cancers including gliomas (28). It heterodimerizes with constitutively expressed subunit HIF-1 $\beta$ to form HIF-1, a basic helix-loop-helix structure that regulates the transcription by specifically recognizing a short consensus HRE (hypoxia responsive element) sequence in the promoter of hypoxia responsive genes. HRE sequence is characterized by the presence of a consensus core CGTG found in all known HIF-1 $\alpha$-responsive promoters (29). A multiple sequence alignment ClustalW2 program revealed that the consensus core was present in all CD133 promoters from P1 to P5. Interestingly, the analysis showed that a sequence of 12 nucleotides present in P5 (known to be functional in stem cells) TACGTGCTCTGGnucleotides 5416-542 matched perfectly with that present in the [+656/+667] HRE sequence of the human IGFBP-1 gene (30). Hence, this sequence represents a potential target for the binding of HIF-1 in glioblastoma cells.

To determine the potential influence of HIF on regulating the expression of $\mathrm{AC133}$, cobalt chloride $\left(\mathrm{CoCl}_{2}\right)$, which inhibits the degradation of $\operatorname{HIF}$ (31), and the shRNA knockdown strategy against HIF-1 $\alpha$ were used. As HIF-1 $\alpha$ stabilization has been shown to increase from moderate to severe hypoxia while not induced under ambient air (32), in order to try getting its level maximal, the hypoxia-mimetic $\mathrm{CoCl}_{2}$ was used already from the $3 \% \mathrm{O}_{2}$ condition. When GlioA cells were incubated for $24 \mathrm{~h}$ with 100 or $150 \mu \mathrm{M}$ of $\mathrm{CoCl}_{2}$ in low $\mathrm{pO}_{2}$ conditions, no significant change was observed in $\mathrm{AC} 133$ expression as compared to control culture (Fig. 2). In contrast, $\mathrm{CoCl}_{2}$ treatment increased the expression of $\mathrm{AC} 133$ in GlioB and GlioC ( $+36-41 \%$ for GlioB and $+41-56 \%$ for GlioC) (Fig. 2). We further address the impact of HIF- $1 \alpha$ inhibition on $\mathrm{CoCl}_{2}$ responding glioblastoma cell types. Transcriptional down-regulation of HIF- $1 \alpha$ mRNA with a lentiviral shRNA-based system performed on GlioB (knockdown efficency of $\sim 80 \%$ and GlioC (knockdown efficiency of 

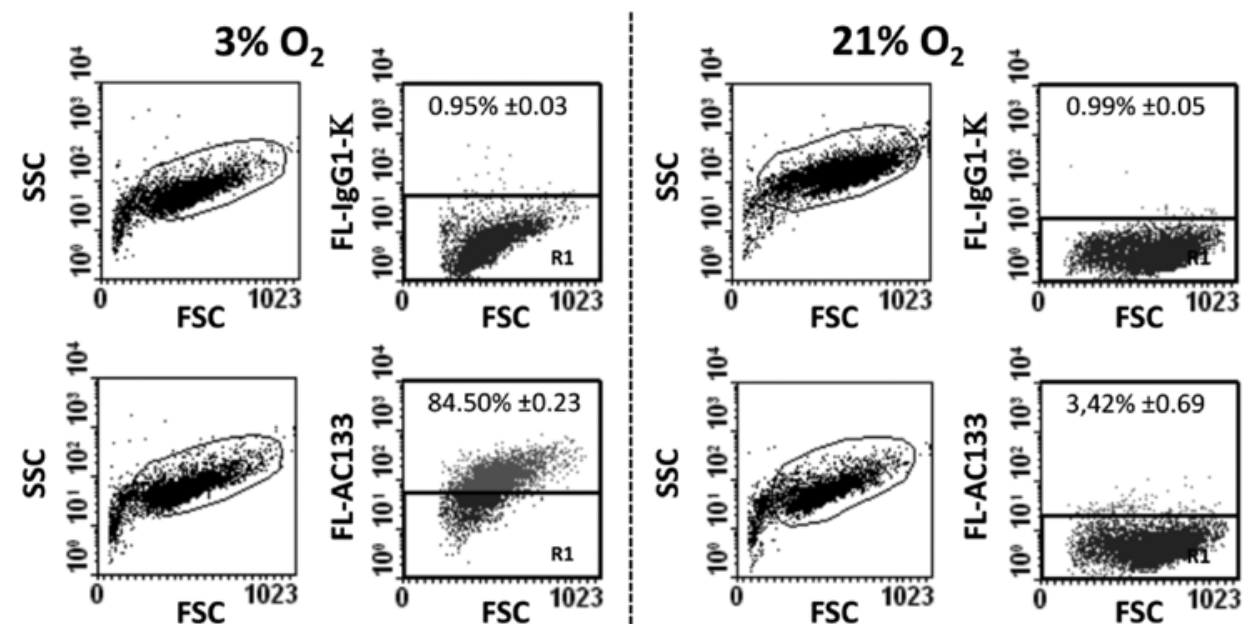

\section{$\frac{\underline{\underline{o g}}}{\overline{\underline{\sigma}}}$}
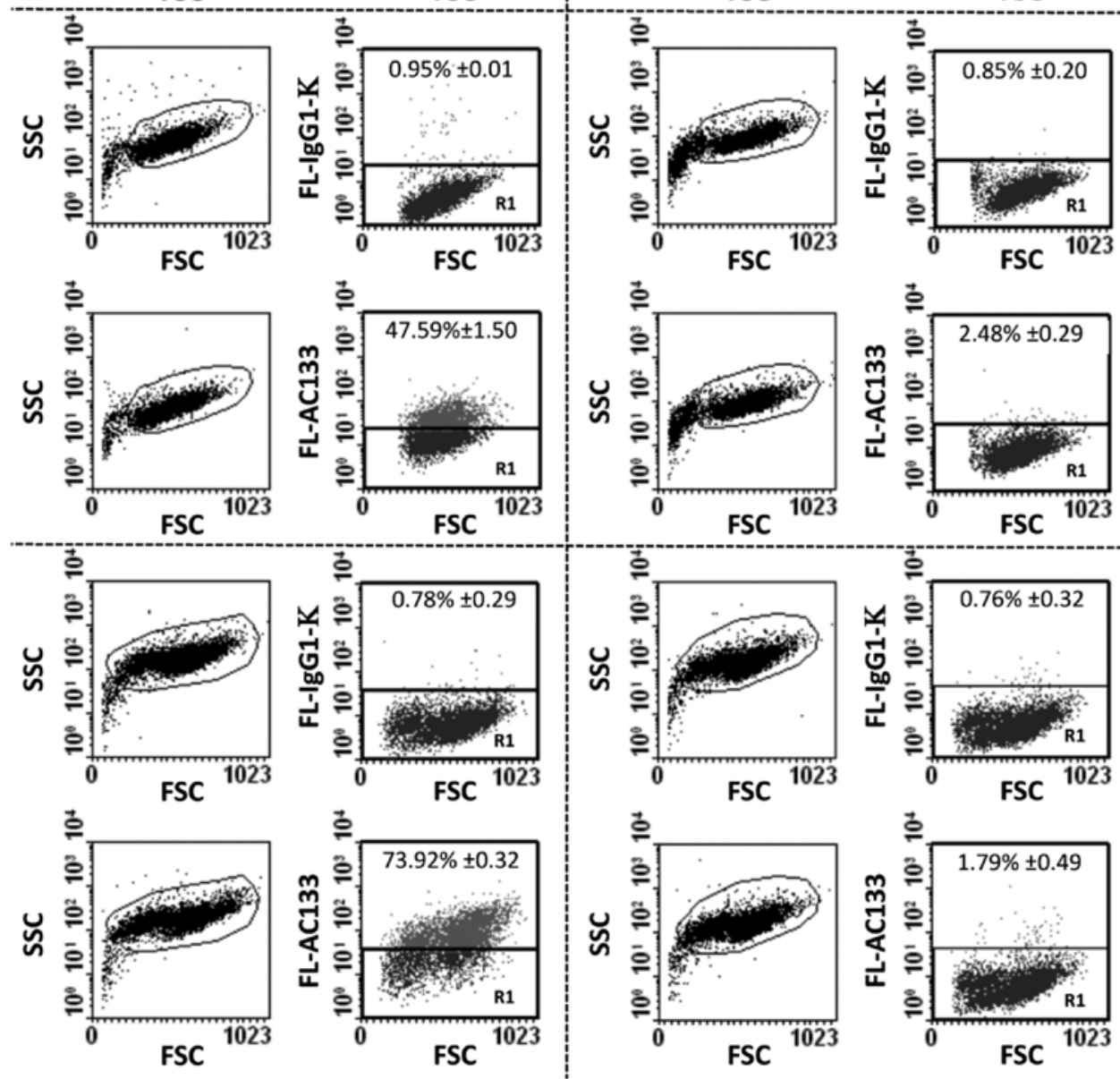

\section{$\frac{\mathrm{og}}{\overline{0}}$}

Figure 1. Greater percentage of $\mathrm{AC} 133$ positive cells are obtained in glioblastoma cells cultured at low $\mathrm{pO}_{2}$. GlioA, GlioB, and GlioC glioblastoma primary

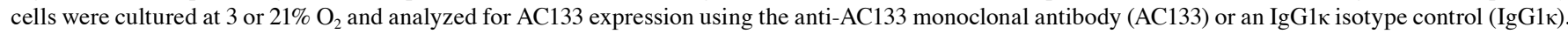
The FITC fluorescence after application of the corresponding secondary antibody is expressed in geometric mean arbitrary units. FSC represented the forward scattering. Indicated percentages represent relative cell numbers that were up to the gated isotype control cells reported on each panel (gate R1). Dot plot profiles illustrate a representative experiment of at least a triplicate, at passage $21(\mathrm{GlioA})$, passage 14 (GlioB) and passage $11(\mathrm{GlioC})$ at 3 or $21 \% \mathrm{O}_{2}$.

$\sim 65 \%$ (Fig. 3 left panels) was associated with a $80-90 \%$ reduction in AC133 expression for GlioB, but had no impact on AC133 expression for GlioC (Fig. 3 right panels).

Human glioma cells exposed to different oxygen tensions in vitro do not behave equally following orthotopic transplantation in immunodepleted mice. Having established a role for oxygen tension and HIF-1 $\alpha$ in regulating $\mathrm{AC} 133$ in vitro, we wished to further address whether tumor development and AC133 expression were affected by the expansion of human glioblastoma cells under different oxygen tension culture conditions. For this purpose, we focused on the cell types for which tumors were detected through MRI monitoring within 3 months after stereotactic injection of glioblastoma cells in the right striatum of immunodepleted mice, namely GlioA and GlioB (Fig. 4). Kaplan-Meyer curves shown in Fig. 4A revealed that 


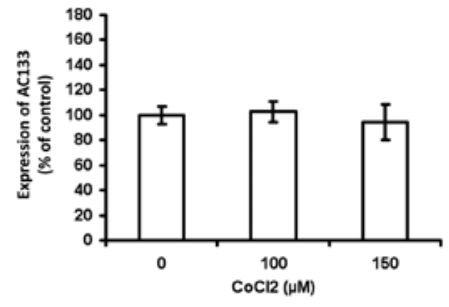

GlioA

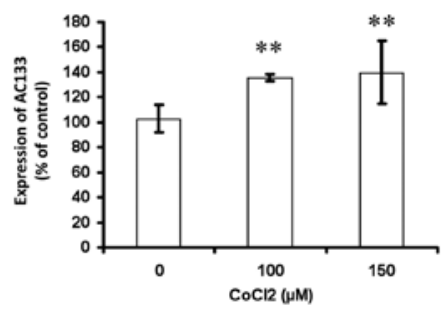

GlioB

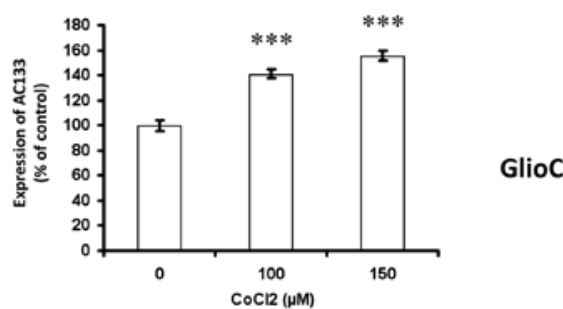

Figure 2. AC133 expression was up-regulated by $\mathrm{CoCl}_{2}$ treatment in glioblastoma cells. GlioA, GlioB, and GlioC primary human glioblastoma cells cultured at $3 \% \mathrm{O}_{2}$ were incubated with 0,100 and $150 \mu \mathrm{M} \mathrm{CoCl}_{2}$ for $24 \mathrm{~h}$ and then analyzed for AC133 expression by flow cytometry. Results are expressed as percentage of control, representing the geomean fluorescence intensity levels obtained after immunostaining of AC133 for cells treated with vehicle alone. Results represent mean \pm SEM of three independent experiments. Dunnett's test: ${ }^{* *} \mathrm{p}<0.01,{ }^{* * *} \mathrm{p}<0.001$
GlioA cell cultures at $3 \% \mathrm{O}_{2}$ were more aggressive than GlioA cells cultured at $21 \% \mathrm{O}_{2}$. In contrast, no significant differences in Kaplan-Meier curves were observed on GlioB. However, tumors caused by the implantation of GlioA cultured at $3 \% \mathrm{O}_{2}$ prior to injection were detected earlier than the tumors arising from GlioA cultured under $21 \% \mathrm{O}_{2}$ (Fig. 4B). Indeed, mice injected with the cells cultured at $3 \%$ developed a detectable tumor within 3 months post-injection (average tumor size $32 \pm 8$ $\mu \mathrm{l}(\mathrm{n}=8)$ ], whereas a similar size was observed 5 months postinjection of GlioA cells initially cultured at $21 \% \mathrm{O}_{2}$.

Interestingly, although no differences were observed on Kaplan-Meier curves, GlioB cultured at 21 vs. $3 \% \mathrm{O}_{2}$ appeared to differ on MRI images. When GlioB cells were cultured in vitro at $21 \% \mathrm{O}_{2}$ prior injection, brain tumor occurred within 2 months [average tumor size $23 \pm 13 \mu 1(\mathrm{n}=8)$ ], whereas injection of cells cultured at $3 \% \mathrm{O}_{2}$ reached such a size after 3 months [average tumor size $34 \pm 21 \mu \mathrm{l}(\mathrm{n}=6)$ ] (Fig. 4B). Examined together, the data indicate that culture conditions are likely to exhibit a real impact on tumor aggressiveness in vivo, underlying the fact that the choice of culture parameters can modulate cell behavior in vivo.

Extinction of AC133 expression of human glioma cells exposed to low oxygen tension in vitro prevents in vivo re-expression after orthotopic transplantation in immunodepleted mice. In order to address human AC133 expression in mice with tumor growth, a study was carried out on mice $24 \mathrm{~h}$ post-injection of $\mathrm{AC} 133$ positive cells to validate AC133 immunohistochemical detection using the AC133 antibody or 293C 3 antibody, both recognizing two different human epitopes of the CD133 protein (Fig. 5A).

\section{GlioB}
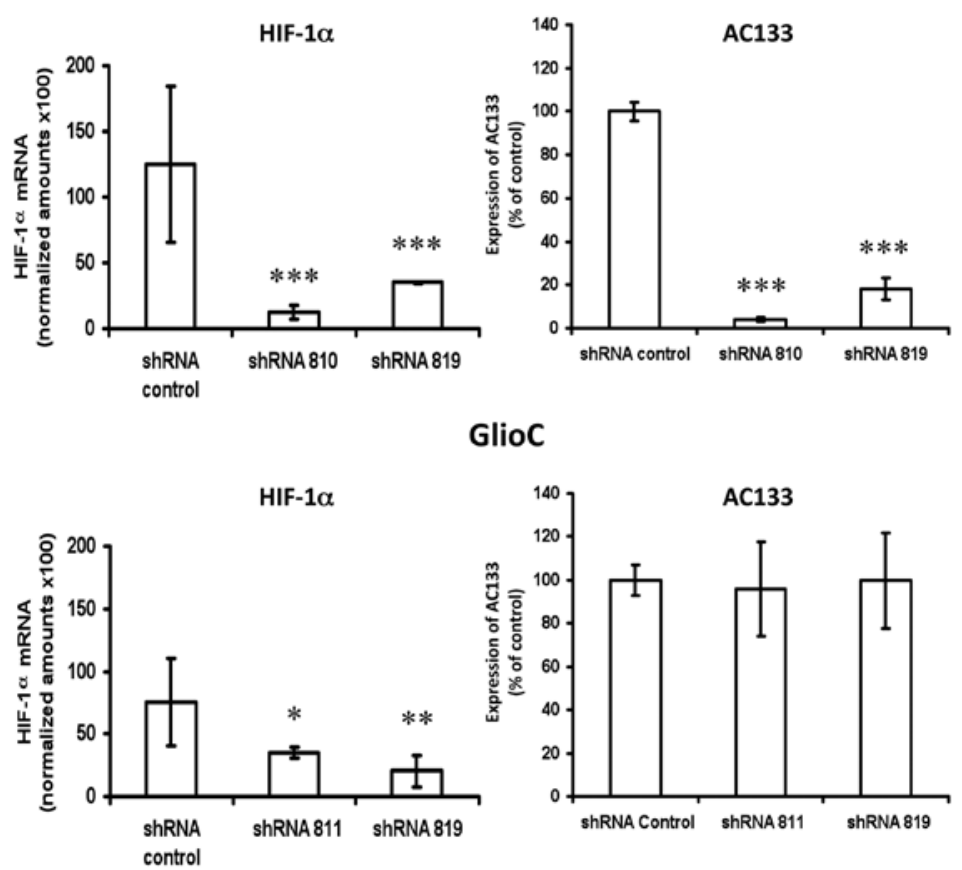

Figure 3. HIF-1 $\alpha$ knockdown led to a reduced AC133 expression at 3\% $\mathrm{O}_{2}$ in GlioB cells but not in GlioC. Left panels show that transfection of GlioB and GlioC cells with specific shRNA against HIF-1 $\alpha$ RNA $(810,811$ or 819$)$ in HIF-1 $\alpha$ mRNA levels when compared with irrelevant shRNA control as determined by RT-qPCR. Results are expressed in normalized amounts as indicated in Materials and methods. Right panels indicate that while knockdown of HIF-1 $\alpha$ resulted in dramatic inhibition of AC133 expression in GlioB as assessed by flow cytometry, no effect was observed in GlioC. Results are expressed as percentage of control, representing the geomean fluorescence intensity levels obtained after immunostaining of AC133 for cells treated with shRNA control. They also represent mean \pm SEM of three independent experiments. Dunnett's test: ${ }^{*} \mathrm{p}<0.05,{ }^{* *} \mathrm{p}<0.01,{ }^{* * * *} \mathrm{p}<0.001$. 
A

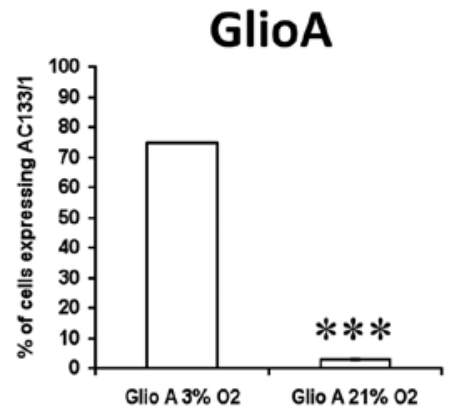

B

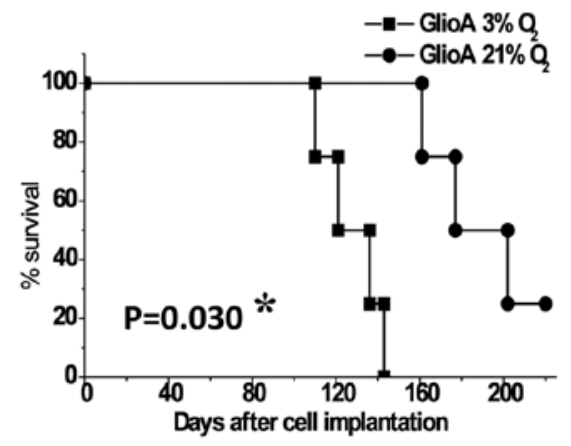

C

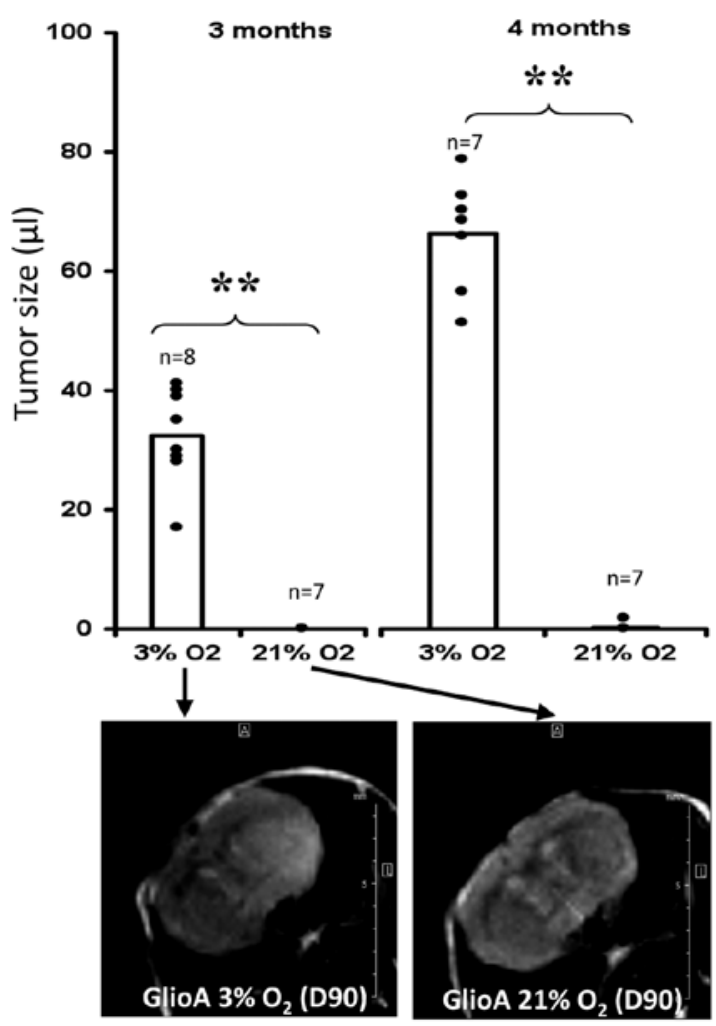

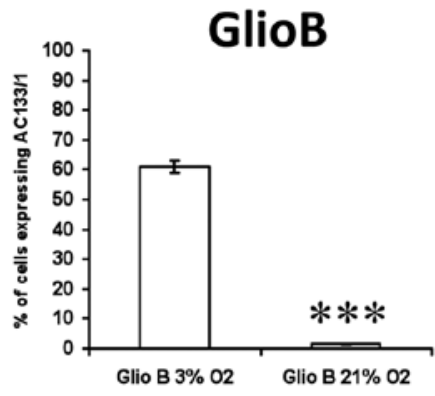

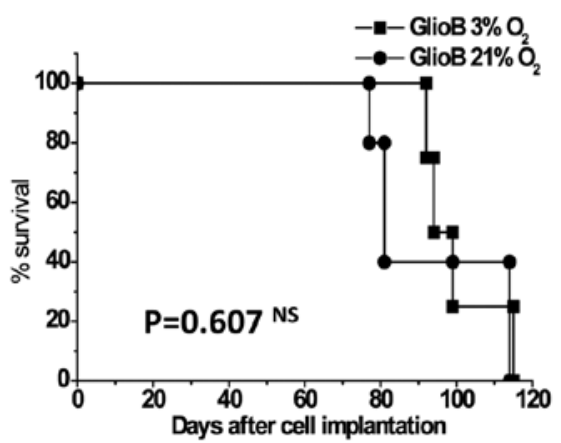

GlioB

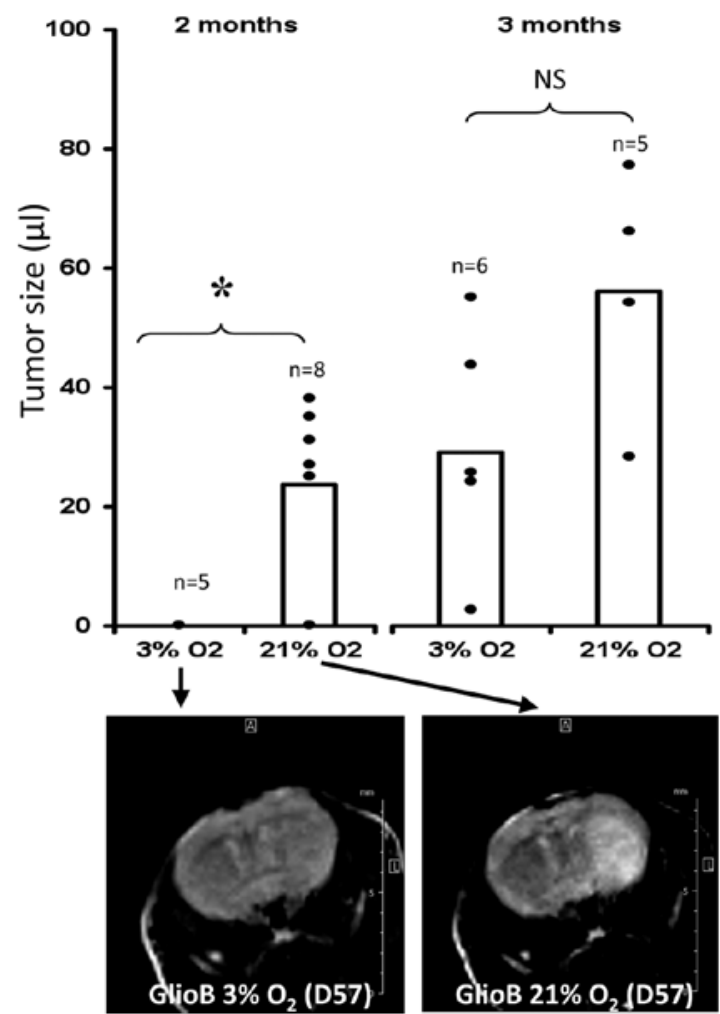

Figure 4. Culturing glioblastoma primary cells at 3 or $21 \% \mathrm{O}_{2}$ resulted in distinct cell behavior in vivo. (A) Flow cytometry analysis of AC133 expression before implantation confirms that GlioA and GlioB cells cultured at $3 \% \mathrm{O}_{2}$ expressed more $\mathrm{AC} 133$ than did cells cultured at $21 \% \mathrm{O}_{2}$. (B) Kaplan-Meier survival curves following implantation of 50,000 cells into the right striatum of female SCID mice revealed that cells cultured at $3 \% \mathrm{O}_{2}$ were more aggressive than their $21 \% \mathrm{O}_{2}$ counterparts for GlioA but nor for GlioB. Gehan-Wilcoxon test: NS, not significant; ${ }^{p}<<0.05$. (C) Measurement of tumor sizes assessed by MRI analysis and corresponding representative MRI images for mice implanted with GlioA or GlioB. Note that although tumors obtained with GlioB grown at $3 \% \mathrm{O}_{2}$ were not detectable at 2 months after brain implantation, they close in on their $21 \% \mathrm{O}_{2}$ counterparts 1 month later, thus revealing distinct growth modalities and density contrast at a given point in time for cells maintained in culture at 3 versus $21 \% \mathrm{O}_{2}$. Mann-Whitney $\mathrm{U}$ test: NS, not significant; ${ }^{*} \mathrm{p}<0.05 ;{ }^{* *} \mathrm{p}<0.01$.

Applying this technique to brain tumors collected at the end point of the experiment revealed that when the injected cells were initially cultured at $3 \% \mathrm{O}_{2}, \mathrm{AC} 133$ was still detected, and this for both GlioA and GlioB cells (Fig. 5B). However, AC133 was detected in limited clusters within the tumor, suggesting that not all the tumor cells had kept the AC133 phenotype. The 
A
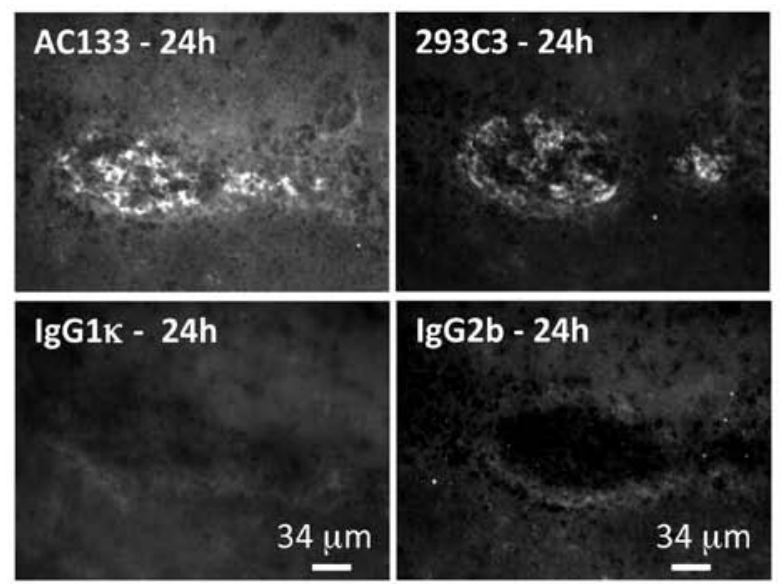

B
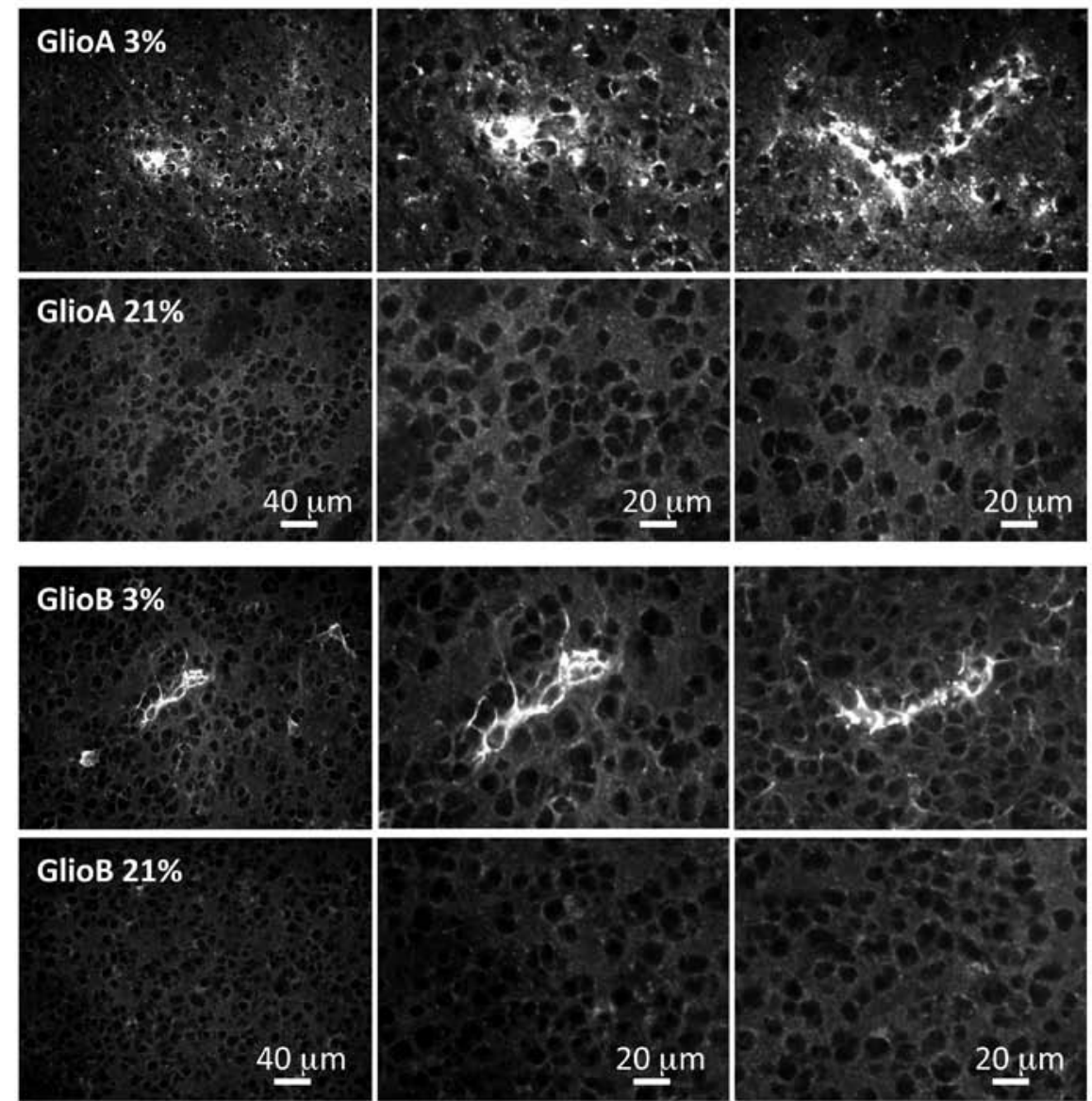

Figure 5. AC133 was not re-expressed in vivo in glioblastoma tumors obtained from cells cultured at $21 \% \mathrm{O}_{2}$ while maintained in tumors derived from cells grown at 3\% $\mathrm{O}_{2}$. (A) Validation of the immunohistochemical detection of AC133. Analysis was initially performed using AC133 and 293C 3 antibodies as well as respective isotype controls (IgG1א and IgG2b) on mouse brain adjacent cryosections $24 \mathrm{~h}$ after implantation of 50,000 GlioA glioblastoma cells grown at $3 \% \mathrm{O}_{2}$ known to express AC133 in vitro. Note common staining characteristics between AC133 and 293C3. Also note the absence of background when using isotype controls at the same concentrations. (B) Although AC133 was detected in discrete areas of both GlioA and GlioB tumors derived from cells grown at $3 \% \mathrm{O}_{2}$, it was not found on brain tumors derived from cells grown at $21 \% \mathrm{O}_{2}$.

same approach on tumors arising from cells cultured at $21 \% \mathrm{O}_{2}$ did not reveal any $\mathrm{AC} 133$ expression (Fig. 5B), indicating that neither GlioA nor GlioB cells grown in $21 \% \mathrm{O}_{2}$ before injection gave rise to AC133 cells in vivo.

\section{Discussion}

Consequences of the $21 \%$ standard $\mathrm{pO}_{2}$ culture condition on glioblastoma phenotypes. To address cancer cell behavior in vivo and in vitro, cancer cell cultures are generally performed under $5 \% \mathrm{CO}_{2}$ combined to classical atmospheric conditions of approximately $21 \% \mathrm{O}_{2}(160 \mathrm{~mm} \mathrm{Hg})$. However, $\mathrm{pO}_{2}$ values do not exceed $12 \% \mathrm{O}_{2}(95 \mathrm{~mm} \mathrm{Hg})$ in the blood and vary from 1 to $5 \%(6-34 \mathrm{~mm} \mathrm{Hg}$ ) in normal tissues including the brain (33). Moreover, a characteristic feature of advanced solid tumors is to display hypoxic tissue areas $\left(\mathrm{pO}_{2} \leq 0.4 \%\right.$ or $\left.2.5 \mathrm{~mm} \mathrm{Hg}\right)$ due to insufficient vascularization, oversize tumor mass, and necrosis (34). Thus, an atmosphere containing $21 \% \mathrm{O}_{2}$ should be physio- 


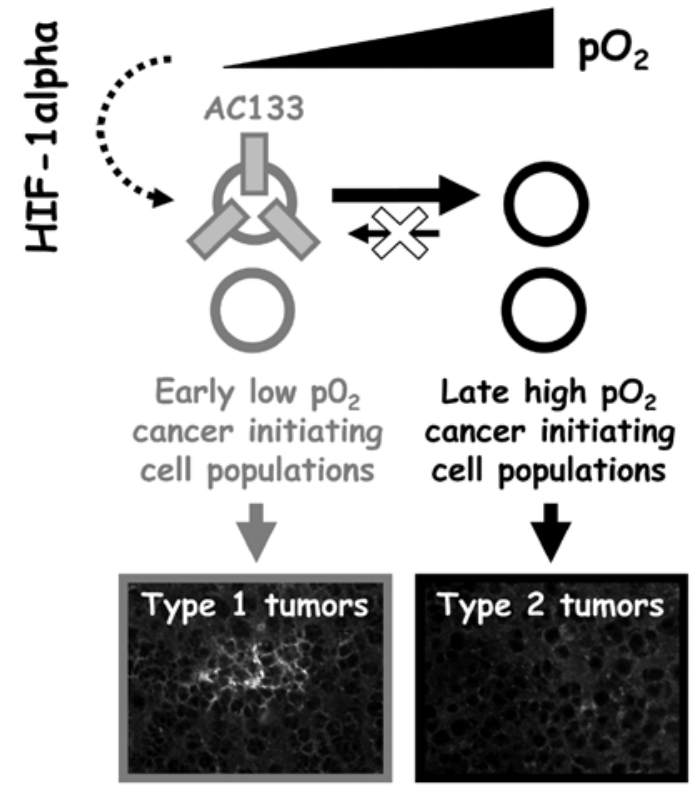

Figure 6. Model defining the relationships between the environmental $\mathrm{pO}_{2}$ and the AC133 phenotype. During gliomagenesis, high oxygen tension may be a component of the cancer initiating cell niche that drives an early-to-late cancer initiating cell switch. In this situation, the irreversible loss of AC133 expression would be perceived as a witness of glioblastoma cell maturation. Instead of being a marker of tumorigenicity, aggressiveness, or oxygen supply, AC133 notably regulated by HIF-1 $\alpha$ therefore represents a hallmark of glioblastoma cell non-exposure to high oxygen tension. Thus, early cancer cell populations that contain AC133-positive cells formed type 1 tumors that continue to express AC133, while late AC133-negative cancer cell developed type 2 tumors which did not re-express AC133.

logically considered hyperoxic. In the present study, although glioblastoma cells were cultured as three-dimension neurospheres, a condition that lowers $\mathrm{pO}_{2}$ due to the gradient of $\mathrm{O}_{2}$ diffusion from the external to the inner part of the spheres, our data demonstrated that in vitro $\mathrm{pO}_{2}$ ranges obtained at 3 versus $21 \% \mathrm{O}_{2}$ resulted in distinct cell behavior in vivo. Tumor aggressiveness was higher for GlioA when cultured at 3 versus $21 \%$ $\mathrm{O}_{2}$. MRI detection of GlioB grown at $3 \%$ was delayed when compared to GlioB grown at $21 \%$, while ultimately giving rise to similar adverse clinical effects. Moreover, AC133, typically found on fresh human glioblastoma biopsy specimens (21) or on short-term primary glioblastoma cultures [ $(3,13)$; our study]; was maintained after expansion in vitro at $3 \% \mathrm{O}_{2}$ while lost at $21 \%$ $\mathrm{O}_{2}$ and not re-expressed after cell implantation in vivo. These combined findings stressed that $\mathrm{pO}_{2}$ values obtained at $3 \% \mathrm{O}_{2}$ preserve better the AC133 phenotype of glioblastoma cells than do $\mathrm{pO}_{2}$ values obtained through the standard $\mathrm{O}_{2}$ atmospheric tension. Our results confirmed, therefore, that a low $\mathrm{pO}_{2}(\leq 3 \%$ $\mathrm{O}_{2}$ or $24 \mathrm{~mm} \mathrm{Hg}$ ) should be considered a basic condition to study glioblastoma cell behavior in their current microenvironment. As such, the fact that $\mathrm{pO}_{2}$ irreversibly changes the phenotype of glioblastoma cell populations is also reminiscent of the effects of serum and laminin on gene expression profiles, expression of stem cell makers, and glioma invasiveness $(3,35,36)$. As variations of $\mathrm{pH}$, the traditional $21 \% \mathrm{O}_{2}$ represents a new environmental stress for glioblastoma cells that inevitably triggers alterations of their differentiation, genetic and epigenetic status, and survival. Considering tumor heterogeneity, selection of glioblastoma cell clones will therefore be different at 3 and $21 \% \mathrm{O}_{2}$. As such, low oxygen tension is often perceived as an obstacle for chemo- and radiotherapy due to the induction of several resistance genes $(13,36)$, DNA repair or methylation (22), miRNA expression (37), and maintenance of stemness (38). Conversely, high oxygen tension represents an oxidative stress that may be associated with the selection of cells that are well-equipped for reactive oxygen species detoxification (39).

Is AC133 a marker of BTSC non-chronic exposure to high oxygen tension? AC133 has initially been described as a marker of hematopoietic stem cells $(9,11)$, while then associated with embryonic stem cells (40) and a variety of somatic stem cells (41). AC133 was also recognized as a putative cancer stem cell marker in blood, brain, colon, prostate, lung, breast, liver, and skin cancers $(12,41)$. Although the BTSC hypothesis was strongly supported by recent data $(4,42,43)$, the idea of a responsibility of cancer stem cells in glioblastoma development remains to be documented (44) and does not exclude the role of clonal selection (45). We emphasize that if the hypothesis of brain cancer initiating cells is correct, the loss of AC133 does not preclude their occurrence. We did establish that GlioA and GlioB that do not contain high AC133 expressing cells when cultured at $21 \% \mathrm{O}_{2}$ self-renew in vitro and do form tumors in vivo. The data give further significance to the originally established unique ability of immunosorted AC133-positive cells to form brain tumors $(2,3,13,46)$ and corroborate the fact that AC133-negative cells are also capable of doing so $(47,48)$. Thus, high AC133 expression is not a marker of every cancer initiating cells within brain tumors.

Sorted AC133-positive cells have been described as more aggressive than their AC133-negative counterparts $(2,3,13)$. Our data proved that when considering the full cancer cell population, the major reduction in $\mathrm{AC} 133$ expression at high versus low $\mathrm{pO}_{2}(87.6 \%$, GlioB, Table I) as well as in $\mathrm{AC133}$ positive cell numbers (from 47.59 to $2.48 \%$, GlioB, Fig. 1) allows for the development of tumors that are similarly aggressive. Thus, AC133 does not appear to be a general marker of tumor aggressiveness.

Low oxygen tension was associated with the stem cell-like properties of AC133-positive glioblastoma cells (26). As we have confirmed here that this also resulted in high levels of AC133, one might assume that AC133 expression constitutes a witness of low oxygen tension. The presence of putative HRE in Prominin-1 promoters combined with the modulation of AC133 expression by $\mathrm{CoCl}_{2}$ treatment and HIF-1 $\alpha$ shRNA knockdown supported this assertion. Previous data obtained with siRNA against HIF-1 $\alpha$ (49), or instead with an oxygen stable HIF-1 $\alpha$ construct (50), also corroborated this, with a significant role for HIF-1 $\alpha$. Interestingly, in contrast to what happen in glioblastoma, in gastric, colorectal and lung cancer cell lines Matsumoto et al established an inverse correlation between HIF-1 $\alpha$ and CD133 expression thus indicating tissue specificities for the regulation of CD133 by HIF-1 $\alpha$ (51). However, $\mathrm{CoCl}_{2}$ did not induce $\mathrm{AC} 133$ in GlioA $\mathrm{O}_{2}$, and $\mathrm{HIF}-1 \alpha$ shRNAs were not able to reduce AC133 expression in GlioC. Although constitutive expression of AC133 might be maximal in GlioA, and HIF-2 is likely to compensate for the loss of HIF-1 $\alpha$ in GlioC $(21,52)$, HIF-independent pathways may be involved in the AC133 regulation by hypoxia. A variety of these recognizable cell signals that translate to environmental 
$\mathrm{O}_{2}$ changes have already been described, including: reactive oxygen species (53), thiol-based sensors (53), the transcriptional co-activator PGC-1 $\alpha$ (54), or mTOR inhibition via the AMPK/ TSC2/Rheb pathway (55). Regardless of the signaling pathway involved in regulating $\mathrm{AC} 133$ by $\mathrm{pO}_{2}$, we have established in our study that the loss of $\mathrm{AC} 133$ at $21 \% \mathrm{O}_{2}$ in vitro (data not shown) and in vivo following glioma cell implantation in mouse brains was irreversible. This lack of re-expression of $\mathrm{AC} 133$ therefore supported the fact that $\mathrm{AC} 133$ is not a genuine marker of hypoxia in glioblastoma. Indeed, low $\mathrm{pO}_{2}$ commonly involved in glioblastoma growth and aggressiveness $(23,24)$ should be present within GlioA and GlioB tumors, which was supported by a reduced vascularization observed using CD31 labeling (data not shown). One-way regulation of AC133 by $\mathrm{pO}_{2}$ might be explained by the acquisition of a new pattern of transcriptional activators or a new DNA methylation status of glioblastoma cells at $21 \%(56,57)$.

As AC133 does not attest to the glioma cell capability of forming tumors or to glioblastoma aggressiveness or low oxygen tension, we propose that it represents a witness of glioblastoma cell non-exposure to high oxygen tension. The presence of AC133 positive glioblastoma cell populations that have also been established at ambient oxygen setting could be explain in this context by creation of hypoxic gradients within the growing glioma spheres (58). This fact would be attenuated by chronic exposure of cells to high oxygen tension through sequential dissociation and re-plating. Hence, similarly to developmental cues that lead to irreversible maturation of early-to-late neural stem cell differentiation during development such as FGF (59), high oxygen tension may represent a component of the BTSC niche that drives an early-to-late BTSC switch during gliomagenesis. If EGF receptor expression represents a witness of the acquired phenotype for neural stem cell maturation, loss of AC133 would be a witness of BTSC maturation. To support this assertion, the loss of AC133 expression has been associated with cancer stem cell differentiation in glioblastoma (60) and in colon cancer (61). Moreover, use of glioma cell differentiation factors such as retinoic acid lead to down-regulation of AC133 expression (62). In addition, transdifferentiation of tumor cells into vessel formation was recently associated with stemness phenotype and hypoxia in glioblastoma (63). Thus, irreversible AC133-loss may also have an impact on this epithelial to mesenchymal transition reciprocally. Two types of tumors could therefore be obtained from non-sorted human glioblastoma cells expanded in vitro: type 1 tumors obtained from $3 \% \mathrm{O}_{2}$-expanded cells (expressing $\mathrm{AC} 133$ ) and type 2 tumors obtained from $21 \% \mathrm{O}_{2}$-expanded cells (no AC133 expression) (Fig. 6).

In conclusion, our present study underlines that non-physiological oxygen tension alters subsequent in vitro expansion and in vivo development of non-sorted human glioblastoma cells. With the preservation of AC133 expression, which can result from the prevention of AC133-positive cell death or from continuous prominin-1 gene expression, the $3 \% \mathrm{O}_{2}$ expansion condition mirrors much the biological reality. Thus, the timing of environmental $\mathrm{pO}_{2}$ variations likely reflects a changing pattern of plasma membrane protein expression during glioblastoma growth that is associated with cell heterogeneity and resistance. The fact AC133 was here associated with an early glioblastoma phenotype suggests that identification of downstream cancer initiating cell markers as well as evaluation of relative anticancer drug sensitivity of type I and type II tumors (Fig. 6) would also be helpful in the development of anti-glioblastoma strategies.

\section{Acknowledgements}

We would like to thank Catherine Guillet, Julien Daligault, and Laurence Preisser (Service Commun de Cytométrie et d'Analyse Nucléotidique, SCCAN, Angers, France) for their skillful technical support. We are also grateful to Pierre Legras and Jérôme Roux from the Service Commun d'Animalerie Hospitalo-Universitaire (SCAHU, Angers, France). La Ligue Nationale Contre le Cancer 'Equipe Labellisée 2007' and Le Cancéropôle Grand-Ouest throughout the 'Réseau Gliome Grand-Ouest' (REGGO) and the 'Axe Cellules Souches et Cancer' supported this work. Erika Bourseau-Guilmain was a fellow of the Conseil Général de Maine-et-Loire and the Ligue Nationale Contre le Cancer. We also acknowledge the Comité Départemental de Maine-et-Loire de la Ligue Contre le Cancer.

\section{References}

1. Ignatova TN, Kukekov VG, Laywell ED, Suslov ON, Vrionis FD and Steindler DA: Human cortical glial tumors contain neural stem-like cells expressing astroglial and neuronal markers in vitro. Glia 39: 193-206, 2002.

2. Singh SK, Clarke ID, Terasaki M, et al: Identification of a cancer stem cell in human brain tumors. Cancer Res 63: 5821-5828, 2003.

3. Singh SK, Hawkins C, Clarke ID, et al: Identification of human brain tumour initiating cells. Nature 432: 396-401, 2004.

4. Jacques TS, Swales A, Brzozowski MJ, et al: Combinations of genetic mutations in the adult neural stem cell compartment determine brain tumour phenotypes. EMBO J 29: 222-235, 2010.

5. Visvader JE and Lindeman GJ: Cancer stem cells in solid tumours: accumulating evidence and unresolved questions. Nat Rev Cancer 8: 755-768, 2008

6. Mayol JF, Loeuillet C, Herodin F and Wion D: Characterisation of normal and cancer stem cells: one experimental paradigm for two kinds of stem cells. Bioessays 31: 993-1001, 2009.

7. Mao XG, Zhang X, Xue XY, et al: Brain tumor stem-like cells identified by neural stem cell marker CD15. Transl Oncol 2: 247-257, 2009.

8. Bao S, Wu Q, Li Z, et al: Targeting cancer stem cells through L1CAM suppresses glioma growth. Cancer Res 68: 6043-6048, 2008.

9. Miraglia S, Godfrey W, Yin AH, et al: A novel five-transmembrane hematopoietic stem cell antigen: isolation, characterization, and molecular cloning. Blood 90: 5013-5021, 1997.

10. Yin AH, Miraglia S, Zanjani ED, et al: AC133, a novel marker for human hematopoietic stem and progenitor cells. Blood 90: 5002-5012, 1997.

11. Corbeil D, Roper K, Weigmann A and Huttner WB: AC133 hematopoietic stem cell antigen: human homologue of mouse kidney prominin or distinct member of a novel protein family? Blood 91: 2625-2626, 1998

12. Ferrandina G, Petrillo M, Bonanno G and Scambia G: Targeting CD133 antigen in cancer. Expert Opin Ther Targets 13: 823-837, 2009.

13. Bao S, Wu Q, McLendon RE, et al: Glioma stem cells promote radioresistance by preferential activation of the DNA damage response. Nature 444: 756-760, 2006.

14. Zobalova R, McDermott L, Stantic M, Prokopova K, Dong LF and Neuzil J: CD133-positive cells are resistant to TRAIL due to up-regulation of FLIP. Biochem Biophys Res Commun 373: 567-571, 2008.

15. Bao S, Wu Q, Sathornsumetee S, et al: Stem cell-like glioma cells promote tumor angiogenesis through vascular endothelial growth factor. Cancer Res 66: 7843-7848, 2006.

16. Zeppernick F, Ahmadi R, Campos B, et al: Stem cell marker CD133 affects clinical outcome in glioma patients. Clin Cancer Res 14: 123-129, 2008. 
17. Joo KM, Kim SY, Jin X, et al: Clinical and biological implications of CD133-positive and CD133-negative cells in glioblastomas. Lab Invest 88: 808-815, 2008.

18. Garcion E, Naveilhan P, Berger F and Wion D: Cancer stem cells: Beyond Koch's postulates. Cancer Lett 278: 3-8, 2008.

19. Scadden DT: The stem-cell niche as an entity of action. Nature 441: 1075-1079, 2006

20. Calabrese C, Poppleton H, Kocak M, et al: A perivascular niche for brain tumor stem cells. Cancer Cell 11: 69-82, 2007.

21. Li Z, Bao S, Wu Q, et al: Hypoxia-inducible factors regulate tumori-genic capacity of glioma stem cells. Cancer Cell 15 : 501-513, 2009.

22. Pistollato F, Abbadi S, Rampazzo E, et al: Intratumoral hypoxic gradient drives stem cells distribution and MGMT expression in glioblastoma. Stem Cells 28: 851-862, 2010.

23. Panchision DM: The role of oxygen in regulating neural stem cells in development and disease. J Cell Physiol 220: 562-568, 2009.

24. Evans SM, Judy KD, Dunphy I, et al: Hypoxia is important in the biology and aggression of human glial brain tumors. Clin Cancer Res 10: 8177-8184, 2004.

25. Platet N, Liu SY, Atifi ME, et al: Influence of oxygen tension on CD133 phenotype in human glioma cell cultures. Cancer Lett 258: 286-290, 2007

26. McCord AM,Jamal M, Shankavarum UT, Lang FF, Camphausen K and Tofilon PJ: Physiologic oxygen concentration enhances the stem-like properties of $\mathrm{CD} 133^{+}$human glioblastoma cells in vitro. Mol Cancer Res 7: 489-497, 2009.

27. Vandesompele J, De Preter K, Pattyn F, et al: Accurate normalization of real-time quantitative RT-PCR data by geometric averaging of multiple internal control genes. Genome Biol 3 : Research0034, 2002.

28. Zhong H, De Marzo AM, Laughner E, et al: Overexpression of hypoxia-inducible factor lalpha in common human cancers and their metastases. Cancer Res 59: 5830-5835, 1999.

29. Wenger RH, Stiehl DP and Camenisch G: Integration of oxygen signaling at the consensus HRE. Sci STKE 2005: re12, 2005.

30. Tazuke SI, Mazure NM, Sugawara J, et al: Hypoxia stimulates insulin-like growth factor binding protein 1 (IGFBP-1) gene expression in HepG2 cells: a possible model for IGFBP-1 expression in fetal hypoxia. Proc Natl Acad Sci USA 95: 10188-10193, 1998.

31. Yuan Y, Hilliard G, Ferguson T and Millhorn DE: Cobalt inhibits the interaction between hypoxia-inducible factor-alpha and von Hippel-Lindau protein by direct binding to hypoxia-inducible factor-alpha. J Biol Chem 278: 15911-15916, 2003.

32. Vordermark D and Brown JM: Evaluation of hypoxia-inducible factor-1alpha (HIF-1alpha) as an intrinsic marker of tumor hypoxia in U87 MG human glioblastoma: in vitro and xenograft studies. Int J Radiat Oncol Biol Phys 56: 1184-1193, 2003.

33. Csete M: Oxygen in the cultivation of stem cells. Ann NY Acad Sci 1049: 1-8, 2005

34. Vaupel P, Kelleher DK and Hockel M: Oxygen status of malignan tumors: pathogenesis of hypoxia and significance for tumor therapy. Semin Oncol 28: 29-35, 2001.

35. Lee J, Kotliarova S, Kotliarov Y, et al: Tumor stem cells derived from glioblastomas cultured in bFGF and EGF more closely mirror the phenotype and genotype of primary tumors than do serumcultured cell lines. Cancer Cell 9: 391-403, 2006.

36. Shervington A and Lu C: Expression of multidrug resistance genes in normal and cancer stem cells. Cancer Invest 26: 535-542, 2008.

37. Huang X, Le QT and Giaccia AJ: MiR-210-micromanager of the hypoxia pathway. Trends Mol Med 16: 230-237, 2010

38. Pistollato F, Chen HL, Rood BR, et al: Hypoxia and HIFlalpha repress the differentiative effects of BMPs in high-grade glioma. Stem Cells 27: 7-17, 2009.

39. Dringen R, Pfeiffer B and Hamprecht B: Synthesis of the antioxidant glutathione in neurons: supply by astrocytes of CysGly as precursor for neuronal glutathione. J Neurosci 19: 562-569, 1999.

40. King FW, Ritner C, Liszewski W, et al: Subpopulations of human embryonic stem cells with distinct tissue-specific fates can be selected from pluripotent cultures. Stem Cells Dev 18: 1441-1450, 2009.
41. Wu Y and Wu PY: CD133 as a marker for cancer stem cells: progresses and concerns. Stem Cells Dev 18: 1127-1134, 2009.

42. Alcantara Llaguno S, Chen J, Kwon CH, et al: Malignant astrocytomas originate from neural stem/progenitor cells in a somatic tumor suppressor mouse model. Cancer Cell 15: 45-56, 2009.

43. Wang Y, Yang J, Zheng H, et al: Expression of mutant p53 proteins implicates a lineage relationship between neural stem cells and malignant astrocytic glioma in a murine model. Cancer Cell 15: 514-526, 2009.

44. Hill RP: Identifying cancer stem cells in solid tumors: case not proven. Cancer Res 66: 1890-1895, 2006.

45. Adams JM and Strasser A: Is tumor growth sustained by rare cancer stem cells or dominant clones? Cancer Res 68: 4018-4021, 2008.

46. Piccirillo SG, Reynolds BA, Zanetti N, et al: Bone morphogenetic proteins inhibit the tumorigenic potential of human brain tumourinitiating cells. Nature 444: 761-765, 2006.

47. Ogden AT, Waziri AE, Lochhead RA, et al: Identification of A2B $5^{+} \mathrm{CD} 133^{-}$tumor-initiating cells in adult human gliomas. Neurosurgery 62: 505-514, 2008

48. Wang J, Sakariassen PO, Tsinkalovsky O, et al: CD133 negative glioma cells form tumors in nude rats and give rise to CD133 positive cells. Int J Cancer 122: 761-768, 2008

49. Soeda A, Park M, Lee D, et al: Hypoxia promotes expansion of the CD133-positive glioma stem cells through activation of HIF-1alpha. Oncogene 28: 3949-3959, 2009.

50. BarEE, Lin A, Mahairaki V, Matsui W and Eberhart CG: Hypoxia increases the expression of stem-cell markers and promotes clonogenicity in glioblastoma neurospheres. Am J Pathol 177: 1491-1502, 2010

51. Matsumoto K, Arao T, Tanaka K, et al: mTOR signal and hypoxiainducible factor-1 alpha regulate CD133 expression in cancer cells. Cancer Res 69: 7160-7164, 2009.

52. Heddleston JM, Li Z, McLendon RE, Hjelmeland AB and Rich JN: The hypoxic microenvironment maintains glioblastoma stem cells and promotes reprogramming towards a cancer stem cell phenotype. Cell Cycle 8: 3274-3284, 2009.

53. Lopez-Barneo J,Pardal R and Ortega-Saenz P: Cellular mechanism of oxygen sensing. Annu Rev Physiol 63: 259-287, 2001.

54. Arany Z, Foo SY, Ma Y, et al: HIF-independent regulation of VEGF and angiogenesis by the transcriptional coactivator PGC-1alpha. Nature 451: 1008-1012, 2008.

55. Liu L, Cash TP, Jones RG, Keith B, Thompson CB and Simon MC Hypoxia-induced energy stress regulates mRNA translation and cell growth. Mol Cell 21: 521-531, 2006.

56. Tabu K, Sasai K, Kimura T, et al: Promoter hypomethylation regulates CD133 expression in human gliomas. Cell Res 18: 1037-1046, 2008

57. Yi JM, Tsai HC, Glockner SC, et al: Abnormal DNA methylation of CD133 in colorectal and glioblastoma tumors. Cancer Res 68 : 8094-8103, 2008

58. Wion D, Christen T, Barbier EL and Coles JA: $\mathrm{PO}(2)$ matters in stem cell culture. Cell Stem Cell 5: 242-243, 2009.

59. Lillien L and Raphael H: BMP and FGF regulate the development of EGF-responsive neural progenitor cells. Development 127: 4993-5005, 2000

60. Chen R, Nishimura MC, Bumbaca SM, et al: A hierarchy of selfrenewing tumor-initiating cell types in glioblastoma. Cancer Cell 17: 362-375, 2010

61. Kemper K, Sprick MR, De Bree M, et al: The AC133 epitope, but not the CD133 protein, is lost upon cancer stem cell differentiation. Cancer Res 70: 719-729, 2010

62. Campos B, Wan F, Farhadi M, et al: Differentiation therapy exerts antitumor effects on stem-like glioma cells. Clin Cancer Res 16: 2715-2728, 2010.

63. Soda Y, Marumoto T, Friedmann-Morvinski D, et al: Transdifferentiation of glioblastoma cells into vascular endothelial cells. Proc Natl Acad Sci USA 108: 4274-4280, 2011. 